\title{
Comparison of quality of life and functionality in type 2 diabetics with and without insulin
}

\author{
(D) Ana Carolina dos Reis ${ }^{1}$ \\ (iD) Milena Vizioli Cunha' \\ (iD) Maysa Alahmar Bianchin² \\ (iD) Maristella Tonon Rui Freitas ${ }^{3}$ \\ (iD) Lilian Castiglioni ${ }^{4}$
}

\begin{abstract}
1. Graduanda em Medicina - Faculdade de Medicina de São losé do Rio Preto (Famerp), São José do Rio Preto, SP, Brasil 2. Doutora e docente do Departamento de Ciências Neurológicas na Faculdade de Medicina de São José do Rio Preto (Famerp),São José do Rio Preto, SP, Brasil 3. Endocrinologista e professora auxiliar de Ensino do Departamento de Endocrinologia da Faculdade de Medicina de São José do Rio Preto (Famerp), São José do Rio Preto, SP, Brasil 4. Doutora em genética na Faculdade de Medicina de São José do Rio Preto (Famerp), São José do Rio Preto, SP, Brasil
\end{abstract}

http://dx.doi.org/10.1590/1806-9282.65.12.1464

\section{SUMMARY}

INTRODUCTION: Type 2 diabetes mellitus compromises physical, psychological, economic, and social life.

OBJECTIVES: To identify and compare the quality of life, depression, functional performance, and physical activity in patients with type 2 diabetes mellitus who use insulin or not.

METHODS: A observational, descriptive, cross-sectional, comparative study involving 100 patients (50 use insulin and 50 do not) from a Teaching Hospital. Questionnaires used: Identification and Socioeconomic Profile; SF-36; Hospital Anxiety and Depression Scale; Visual Analogue Scale for Pain; Canadian Occupational Performance Measure, and International Physical Activity Questionnaire.

RESULTS: Sample composed predominantly by middle-aged, female, married, retired, and with incomplete elementary school individuals. There is impairment in all domains of quality of life, being more intense in functional capacity, physical limitations, pain, social aspects, limitation by emotional aspects, and mental health $(P<0.05)$. There is a significant prevalence of anxiety or depressive symptoms in the groups, especially in those using insulin. However, the occurrence of the corresponding psychiatric disorders is unlikely ( $P<0.05)$. There was no significant difference in neuropathic pain between the groups $(P=0.2296)$. Functional impairment is similar in both groups regarding self-care activities $(P=0.4494)$ and productivity $(P=0.5759)$, with a greater deterioration of leisure time in patients on insulin $(P=0.0091)$. Most of them practice physical activity, predominantly walking, with no significant difference when comparing the groups $(P>0.05)$, as well as in the other modalities.

CONCLUSION: Insulinized patients present greater impairment of functional capacity and socialization, as well as greater neuropathic pain, anxiety, and depressive symptoms.

DESCRIPTORS: Diabetes mellitus, type 2. Insulin. Quality of life. Mental health. Occupational therapy. Exercise.

\section{INTRODUCTION}

Diabetes mellitus (DM) is a chronic non-transmissible disease, resulting from the inability to produce and/or the non-use of endogenous insulin, which causes hyperglycemia and, consequently, abnormalities in glucose, lipid, and protein metabolism. ${ }^{1.2}$ According to the International Diabetes Federation, 
there are 415 million diabetics in the world, 14 million in Brasil, of which 90\% are type 2, 5-10\% type 1, and $2 \%$ are other types or associated syndromes. ${ }^{2-4}$ There is an estimated increase of $50 \%$ in its prevalence in the next 20 years, and its main risk factors are: female gender, age, high body mass index (BMI), systemic arterial hypertension ( $\mathrm{SAH})$, and family history of diabetes..$^{5.6}$

This disease generates profound impacts related to complications that can be acute (hypoglycemia, ketoacidosis, and hyperosmolar coma) or chronic (cardiovascular disease, renal insufficiency, amputation of limbs, neuropathy, nephropathy, and retinopathy). ${ }^{7}$ Although mortality due to complications has decreased, the quality of life and well-being of diabetic individuals are still very much affected, with changes in work, family, sexuality, physical, social, and emotional well-being, physical changes, and the significance of these changes. ${ }^{1}$

After the diagnosis, it is common to react with anger, revolt, and depression due to biological, psychological, and social changes that influence acceptance and adherence to the treatment of the disease since it requires self-care (adopt healthy behaviors) and the use of long-term medications to avoid complications, thus making the prognosis of type 2 diabetes mellitus (DM2) unfavorable. ${ }^{8}$

Mild/moderate physical exercise increases insulin sensitivity and the muscle uptake of glucose, reduces body fat, improves the heart frequency, and the lipid and glycemic control, among others, in all individuals, promoting physical and mental well-being. ${ }^{9}$

In DM2, often the mere change of lifestyle is not enough; therefore, the combined treatment with medications (oral hypoglycemic agents and/or insulin) aims to achieve levels of glycated hemoglobin (Hba1c) lower than $7 \%$ in order to reduce the risk of micro and macrovascular complications. ${ }^{10}$

Several factors influence the quality of life of diabetic individuals, such as the use of insulin, age, chronic complications, socioeconomic and educational level, psychological factors, knowledge about the disease, and care received. This study will evaluate the different influences of the treatment used - oral hypoglycemic agents or insulin - in quality of life, depression, functional performance, and physical activity in patients with DM2, enabling the development of strategies and intervention programs to promote integral care to diabetic patients.

\section{METHODS}

This is an individual, observational, descriptive, cross-sectional, comparative study carried out at the Outpatient Clinic of Endocrinology of the Hospital de Base in São José do Rio Preto, from August 2016 to April 2017, approved by the Research Ethics Committee of Famerp, decision No. 1,575,216. A total of 100 DM2 patients were included - 50 in the Hypoglycemic Drugs Group- MG - and 50 in the Insulin Group - IG. They were approached while waiting for their medical consultations and agreed to participate by signing the Informed Consent Form.

The participants are patients with a confirmed diagnosis of DM2, who use medications or insulin, aged over 18 years, regardless of sex, socioeconomic conditions, and ethnicity enrolled from a convenience sample.

These patients responded to six questionnaires: Identification Sheet and Socioeconomic Profile; SF-36 Inventory of Quality of Life, grading the general state of health; Hospital Anxiety and Depression Scale HADS, evaluating, separately, anxiety (HADS-A) and depression (HADS-D); the Canadian Occupational Performance Measure - COPM, analyzing the functional capacity; Visual Analogue Scale of Pain - VAS, measuring the intensity of pain; and International Physical Activity Questionnaire - IPAQ, reporting the frequency and duration of physical activities based on the previous week.

Using techniques of descriptive and inferential statistics, we calculated absolute frequencies, percentages, measures of central tendency, and dispersion. We used the Kolmogorov-Smirnov normality test or Fischer's Test and, subsequently, for comparison between groups, the Student's t-test or Mann-Whitney test. A p-value $<0.05$ was considered statistically significant. The software used was Graphpad Instat 3.10 (2009).

\section{RESULTS}

After analyzing the socioeconomic data, we found an average age of $56.12 \pm 13.78$ years and the average time of diagnosis of 10.46 years in the MG and $59.46 \pm 11.48$ years and 12.86 years in the IG, respectively. In our sample, most individuals were female, married, with incomplete basic education, and retired.

The SF-36 Inventory of Quality of life (Table 1), comprising eight scales, scored from 0 to 100 , shows a better quality of life, the higher the score obtained. Among diabetic individuals, all areas were affected, 
in different intensities individually and per domain, with an statistical significance in functional capacity $(\mathrm{P}=0.0002)$, limitation due to physical aspects $(\mathrm{P}=0.0002)$, pain $(\mathrm{P}=0.0076)$, social aspects $(\mathrm{P}<0.0001)$, limitation due to emotional aspects $(\mathrm{P}<0.0001)$ and mental health $(\mathrm{P}<0.0001)$, indicating a greater impairment in the IG.

The analysis of the Hospital Anxiety and Depression Scale - HADS (Figure 1) indicated the presence of anxiety or depression symptoms in a large portion of participants in both groups, but anxiety disorders or depression are unlikely. We can also conclude that individuals in the IG have a significantly higher incidence of anxiety $(\mathrm{P}<0.0001)$ or depression $(\mathrm{P}=0.0001)$.

The intensity of neuropathic pain, as assessed by Visual Analog Scale of Pain - VAS, showed, in the MG, a mean \pm SD of $4.5 \pm 4$.036; mode 0 ; median 5 and maximum and minimum scores of 0 and 10 , respectively,

TABLE 1. STATISTICAL DESCRIPTION OF THE SF-36 INVENTORY OF QUALITY OF LIFE SCORE IN EACH DOMAIN OF THE MG AND IG GROUPS

\begin{tabular}{|c|c|c|c|c|c|c|}
\hline Domain score & & Minimum & Maximum & Median & Mean \pm SD & $\mathrm{P}$ \\
\hline \multirow[t]{2}{*}{ Functional capacity } & $M G$ & 35 & 100 & 85 & $83.6 \pm 16.84$ & \multirow[t]{2}{*}{0.0002} \\
\hline & IG & 5 & 100 & 67.5 & $59.9 \pm 31.72$ & \\
\hline \multirow[t]{2}{*}{ Limitation due to physical aspects } & $M G$ & 0 & 100 & 75 & $66 \pm 35.26$ & \multirow[t]{2}{*}{0.0002} \\
\hline & IG & 0 & 100 & 0 & $35.5 \pm 43.76$ & \\
\hline \multirow[t]{2}{*}{ Pain } & $M G$ & 0 & 100 & 61 & $61.59 \pm 32.11$ & \multirow[t]{2}{*}{0.0076} \\
\hline & IG & 0 & 100 & 40 & $43.32 \pm 32.49$ & \\
\hline \multirow[t]{2}{*}{ Overall health condition } & $M G$ & 25 & 67 & 52 & $50.28 \pm 10.22$ & \multirow[t]{2}{*}{0.0844} \\
\hline & IG & 0 & 100 & 41 & $45.03 \pm 27.01$ & \\
\hline \multirow[t]{2}{*}{ Vitality } & $M G$ & 20 & 85 & 55 & $54.6 \pm 14.06$ & \multirow[t]{2}{*}{0.0929} \\
\hline & IG & 0 & 100 & 45 & $44.7 \pm 27.81$ & \\
\hline \multirow[t]{2}{*}{ Social aspects } & $M G$ & 50 & 100 & 100 & $91 \pm 12.88$ & \multirow[t]{2}{*}{$<0.0001$} \\
\hline & IG & 0 & 100 & 50 & $54 \pm 37.15$ & \\
\hline \multirow[t]{2}{*}{ Limitation due to emotional aspects } & $M G$ & 33.4 & 100 & 100 & $78.68 \pm 29.13$ & \multirow[t]{2}{*}{$<0.0001$} \\
\hline & $I G$ & 0 & 100 & 33.33 & $52.65 \pm 42.10$ & \\
\hline \multirow[t]{2}{*}{ Mental health } & $M G$ & 56 & 96 & 80 & $77.68 \pm 10.44$ & \multirow[t]{2}{*}{$<0.0001$} \\
\hline & $I G$ & 0 & 100 & 60 & $58.56 \pm 25.28$ & \\
\hline
\end{tabular}

SD - Standard deviation. MG - Group who used hypoglycemic medication. IG - Group who used insulin

FIGURE 1. HOSPITAL ANXIETY AND DEPRESSION SCALE (HADS) OF DM2 PATIENTS USING MEDICATION (MG) OR INSULIN (IG)

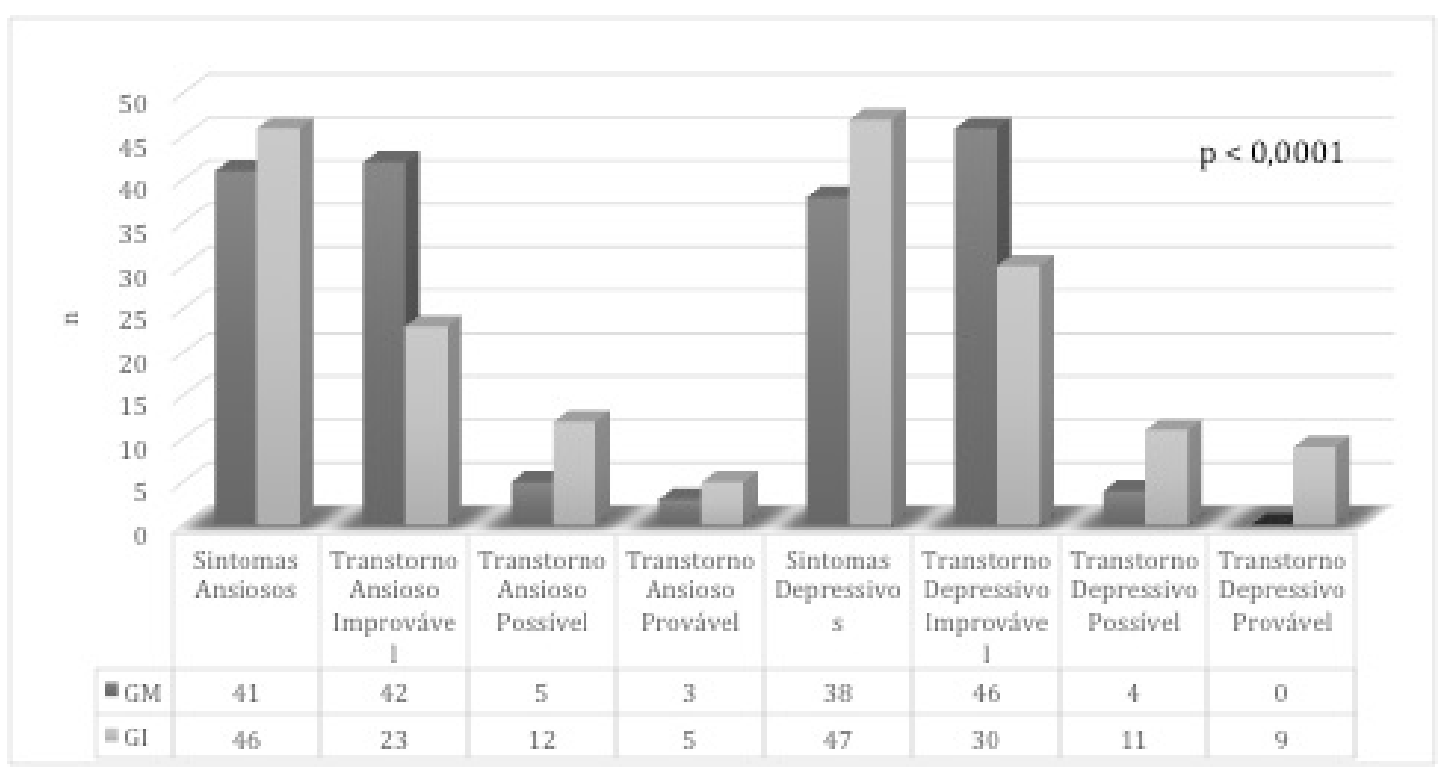


and $62 \%$ (31) of these participants presented NPP, with $16 \%(\mathrm{n}=8)$ reporting living with the worst pain ever experienced (score 10). Regarding the IG, the mean \pm SD obtained was $5.58 \pm 3.703$; mode 0 ; median 5 and maximum and minimum scores of 0 and 10 , respectively; in this group, $74 \%(\mathrm{n}=37)$ presented NPP, with $16 \%(\mathrm{n}=8)$ reporting living with the worst pain ever experienced. Therefore, there was no significant difference in NPP between both groups $(\mathrm{P}=0.2296)$.

The Canadian Occupational Performance Measure - COPM (Table 2) analyzed the impairment of functionality in self-care, productivity, and leisure activities; independence outside the home, domestic activities, and active recreation were the activities most affected in each class, respectively, in both groups. After comparing the results of the MG and the IG, no statistical significance was found regarding impairment of selfcare activities $(\mathrm{P}=0.4494)$ and productivity $(\mathrm{P}=0.5759)$, whereas in relation to leisure, the greatest impairment in the IG was significant ( $\mathrm{P}=0.0091)$, highlighting an important impairment of socialization.

Finally, the International Physical Activity Questionnaire - IPAQ showed that $76 \%$ of individuals of the MG and $68 \%$ of the IG practice physical activity, and walking was the modality with most practitioners in the MG, with $42 \%$, and in the IG, with $52 \%$. However, when comparing both groups, there was no significant difference in adherence to this practice $(\mathrm{P}=0.1636)$, but there was in the following modalities: moderate activities, practiced by $22 \%$ of members in the MG and $44 \%$ in the IG ( $p=0.0696)$; and vigorous activities, with only $2 \%$ of practitioners in the MG and $6 \%$ in the IG $(\mathrm{P}=0.3248)$.

\section{DISCUSSION}

In this study, the mean age of participants was greater than 55 years, with a predominance of females, married, with incomplete basic education, and retired, which is in line with other studies. ${ }^{11}$

The SF36 - Inventory of Quality of Life scores indicate that the areas most affected - worst scores - are in the MG, general health state (50.28), vitality (54.6), and pain (61.59), in comparison with physical aspects (35.5), pain (43.32) and vitality (44.7) in the IG. In spite of equivalences in two domains, the GI, with lower averages, presented greater impairment. The best domains were social aspects (91), functional capacity (83.6), and limitation due to emotional aspects (77.68) in the MG, and functional capacity (59.9), mental health (58.56), and social aspects (54) in the IG. We also found, based on the means, equivalence in two areas, but there is a greater impairment in the IG. The lowest scores of the IG are consistent with the literature, due to the influence of therapy in the patient's quality of life. ${ }^{12}$

We conclude by examining the emotional state of the participants, a high presence of anxiety and/ or depression symptoms in both groups; however, it is not possible to say that those represent a diagnosis of depressive and/or anxiety disorder. Despite this, the probability of symptoms and/or presence of these disorders is significantly greater among individuals in the IG, which is consistent with previous studies and correlates with more advanced disease and more comorbidities and/or complications, which have a direct emotional impact and do not derive directly from insulin. ${ }^{13.14}$ The emotional state is directly related

TABLE 2. DIFFICULTIES REPORTED BY THE PARTICIPANTS IN THE USE OF MEDICATION (MG) AND INSULIN (IG) ACCORDING TO THE CANADIAN OCCUPATIONAL PERFORMANCE MEASURE - COPM

\begin{tabular}{|c|c|c|c|c|c|}
\hline \multicolumn{3}{|c|}{ MG } & \multicolumn{3}{|l|}{ IG } \\
\hline Activity & $\mathrm{n}$ & $\%$ & $\mathrm{n}$ & $\%$ & $P$ \\
\hline \multicolumn{6}{|l|}{ Self-Care } \\
\hline Personal Care & 2 & 4 & 2 & 4 & 0.4494 \\
\hline Functional Mobility & 3 & 6 & 10 & 20 & \\
\hline Independence away from home & 10 & 20 & 14 & 28 & \\
\hline \multicolumn{6}{|l|}{ Productivity } \\
\hline Work & 11 & 22 & 10 & 20 & 0.5759 \\
\hline Domestic Activities & 17 & 34 & 11 & 22 & \\
\hline \multicolumn{6}{|l|}{ Leisure activities } \\
\hline Calm Recreation & 6 & 12 & 4 & 8 & \\
\hline Active recreation & 7 & 14 & 18 & 36 & 0.0091 \\
\hline Socialization & 1 & 2 & 16 & 32 & \\
\hline
\end{tabular}


to the quality of life, interfering in adherence to treatment and other activities beneficial to health. ${ }^{13,15,16}$

Neuropathic pain (NPP), present in both groups with no statistically significant differences in prevalence in the Mg and the IG, differs from previous studies, which showed a higher occurrence of NPP in type 2 diabetic patients from the MG, because those on insulin (IG) get lower blood glucose levels, thus preventing the development and progression of microvascular complications. ${ }^{17}$ The involvement of a large number of the patients studied (62\% in the MG and $74 \%$ in the IG) also differ in relation to other analyses with a lower percentage. ${ }^{18.19}$ The discrepancy in the prevalence of diabetic neuropathy has been reported in some studies, and its possible causes include the age of the population studied, time of diagnosis, control of blood glucose levels, the presence of peripheral arterial disease, and the diagnostic methods employed. ${ }^{19.20}$ There is also interference of the diagnostic instrument, because, through the Visual Analogue Scale of Pain - VAS, patients graded their pain intensity. It is known that comorbidities are confounding factors, because patients may report pain without this necessarily being neuropathic, thus raising results of prevalence, which is an important limitation of the present study. ${ }^{18-20}$

The functional capacity of the participants was evaluated by the Canadian Occupational Performance Measure - COPM and indicated commitment in selfcare activities, productivity, and leisure, the latter with greater impairment in the IG. Similar results have been observed in other studies. ${ }^{21}$ Therefore, DM2 influences functional capabilities, and hyperglycemia, the time of evolution of the disease, and the treatment in use can be aggravating factors. ${ }^{22.23}$

The International Physical Activity Questionnaire IPAQ revealed that the participants are predominantly active, without statistically significant differences when comparing the practice of physical exercises in both groups; the less intense modalities - walking were preferred; adhesion progressively decreases with the increase of activity intensity. This behavior differs from the one described in the literature regarding the percentage of diabetic patients adherents to physical activities; however, it converges regarding the type of activity practiced. Thus, the use of strategies that are simple, inexpensive, and of rapid implementation by a health professional is important and has an impact on the behavior related to physical activity in this population. ${ }^{24.25}$

\section{CONCLUSION}

Diabetes mellitus, a disease caused by the lack of production or difficulty in using endogenous insulin, generates hyperglycemia and metabolic abnormalities, causing loss of functional capacity and quality of life due to the development of peripheral neuropathic pain, retinopathy, nephropathy, anxiety, depression, and changes in lifestyle. Thus, emphasis should be given to the importance of physical exercises for the treatment of endocrinopathy and emotional changes.

In this study, we found that the patients on insulin have, in general, greater impairment of quality of life, functional capacity, and socialization, and report greater neuropathic pain and anxious and depressive symptoms in relation to those who use medications.

These outcomes are explained by the greater physical and emotional discomfort from the use of insulin for blood glucose control, a more advanced stage of the disease, and a greater presence of comorbidities. Therefore, we must develop strategies and intervention programs to promote the integral care of patients with DM2, from the time of diagnosis, to prevent the progression of the disease and its complications, considering the physical and emotional impact of each therapeutic option, and not just the indications based on the control of blood glucose levels.

\section{Contribution of the authors}

Ana Carolina Reis - Concept of the project, data collection and analysis, reference search, and drafting of the article.

Milena Vizioli Cunha - Concept of the project, data collection and analysis, reference search, and drafting of the article.

Maysa Alahmar Bianchin - Advisor.

Maristella Tonon Rui Freitas - Advisor.

Lilian Castiglioni - Statistical analysis. 
MÉTOdos: Estudo individuado, observacional, descritivo, transversal, comparativo envolvendo 100 pacientes (50 utilizam insulina e 50 não) em um hospital escola. Instrumentos utilizados: Ficha de Identificação e Perfil Socioeconômico; SF-36; Escala Hospitalar de Ansiedade e Depressão; Escala Visual Analógica de Dor; Medida Canadense de Desempenho Ocupacional e Questionário Internacional de Atividade Física.

RESULTADOS: Amostra composta, predominantemente, por indivíduos de meia-idade, sexo feminino, casados, ensino fundamental incompleto e aposentados. Há comprometimento de todos os domínios da qualidade de vida, sendo mais intenso nos insulinizados em capacidade funcional, limitação por aspectos físicos, dor, aspectos sociais, limitação por aspectos emocionais e saúde mental ( $P<0,05)$. Importante prevalência de sintomas ansiosos ou depressivos nos grupos, principalmente nos em uso de insulina, porém a ocorrência dos transtornos psiquiátricos correspondentes é improvável $(P<0,05)$. Não houve diferença significativa da DNP entre os grupos $(P=0,2296)$. $O$ prejuízo da funcionalidade é semelhante em relação a atividades de autocuidado $(P=0,4494)$ e produtividade $(P=0,5759)$ nos dois grupos, havendo maior deterioração do lazer em usuários de insulina $(P=0,0091)$. A maioria pratica atividade física, tendo a caminhada a maior adesão, sem diferença significativa ao comparar os grupos $(P>0,05)$, repetindo-se nas demais modalidades.

CONCLUSÃo: Pacientes insulinizados apresentaram maior prejuízo da capacidade funcional e na socialização, assim como referem maiores dores neuropáticas e sintomas ansiosos e depressivos.

PALAVRAS-CHAVE: Diabetes mellitus tipo 2. Insulina. Qualidade de vida. Saúde mental. terapia ocupacional. Exercício.

\section{REFERENCES}

1. Ledón LL. Impacto psicosocial de la diabetes mellitus, experiencias, significados y respuestas a la enfermedad. Rev Cubana Endocrinol. 2012;23(1):76-97.

2. Dalzochio T, Bonho L, Feksa LR, Berlese D. Relationship between depression and diabetes mellitus. Rev Ciênc Méd PUCCAMP. 2014;23(2):91-9.

3. Internatiomal Diabetes Federation. IDF Diabetes atlas. $7^{\text {nd }}$ ed. Bruxelas: Internatiomal Diabetes Federation; 2015.

4. World Health Organization - WHO. Diabetes Programme. Geneva: WHO; 2017. [cited 2017 Aug 5]. Available from: http://www.who.int/diabetes/en/.

5. Higuita-Gutierrez LF, Vargas-Alzate CA, Cardona-Arias, JA. Impacto de la diabetes, el sobrepeso y la obesidad en la calidad de vida relacionada con la salud del adolescente: metanálisis. Rev Chil Nutr. 2015;42(4):383-91.

6. Winkelmann ER, Fontela PC. Condições de saúde de pacientes com diabetes mellitus tipo 2 cadastrados na estratégia saúde da família, em Ijuí, Rio Grande do Sul, 2010-2013. Epidemiol Serv Saúde. 2014;23(4):665-74.

7. Ministério da Saúde. Secretaria de Atenção à Saúde. Departamento de Atenção Básica. Estratégias para o cuidado da pessoa com doença crônica: diabetes mellitus. Brasília: Ministério da Saúde; 2013.

8. Maia MA, Reis IA, Torres HC. Relationship between the users' contact time in educational programs on diabetes mellitus and self-care skills and knowledge. Rev Esc Enferm USP. 2016;50(1):59-65.

9. Galvin EA, Navarro F, Greatti VR. A importância da prática do exercício físico para portadores de diabetes mellitus: uma revisão crítica. Rev Salusvita. 2014;33(2):209-22.

10. Sociedade Brasileira de Diabetes. Diretrizes da Sociedade Brasileira de Diabetes 2014-2015. Medicamentos orais no tratamento do diabetes mellitus: como selecioná-los de acordo com as características clínicas dos pacientes. São Paulo: Sociedade Brasileira de Diabetes, 2015.

11. Santos SA, Rocha PB, Viana LC. Perfil metabólico de pacientes acometidos por diabetes mellitus tipo II: uma construção educativa. Cad Grad Ciênc Hum Soc Unit. 2015;2(3):65-80.

12. Wexler DJ, Grant RW, Witternberg E, Bosch JL, Cagliero E, Delahany L, et al. Correlates of health-related quality of life in type 2 diabetes. Diabetologia. 2006;49(7):1489-97.

13. Bahety P, Agarwal G, Khandelwal D, Dutta D, Kalra S, Taparia P, et al. Occurrence and predictors of depression and poor quality of life among patients with type-2 diabetes: a Northern India perspective. Indian J Endocrinol Metab. 2017;21(4):564-9.
14. Elissen AMJ, Hertrojis DFL, Schaper NC, Bosma H, Dagnelie PC, Henry RM, et al. Differences in biopsychosocial profiles of diabetes patients by level of glycaemic control and health-related quality of life: the Maastricht study. PLoS One. 2017;12(7):e0182053.

15. Mast R, Rauh SP, Groeneveld L, Koopman AD, Beulens JW, Jansen AP, et al. The use of antidepressants, anxiolytics, and hypnotics in people with type 2 diabetes and patterns associated with use: the Hoorn Diabetes Care System Cohort. Biomed Res Int. 2017;2017:5134602.

16. Lunghi C, Moisan J, Grégoire JP, Guénette L. The association between depression and medication nonpersistence in new users of antidiabetic drugs. Value Health. 2017;20(6):728-35.

17. Grote CW, Wright DE. A role for insulin in diabetic neuropathy. Front Neurosci. 2016;10:581.

18. Callaghan BC, Price RS, Feldman EL. Distal symmetric polyneuropathy: a review. JAMA. 2015;314(20):2172-81.

19. Cortez J, Reis C, Cardoso Y, Onofre A, Piovezan AP. Prevalence of neuropathic pain and associated factors in diabetes mellitus type 2 patients seen in outpatient setting. Rev Dor. 2014;15(4):256-9.

20. Ziegler D, Rathmann W, Dickhaus T, Meisinger C, Mielck A; KORA Study Group. Neuropathic pain in diabetes, prediabetes and normal glucose tolerance: the MONICA/KORA Augsburg Surveys S2 and S3. Pain Med. 2009;10(2):393-400.

21. Mendes Z, Guedes S, Guerreiro JP, Inês M, Sousa A, Miranda A. Autovigilância da doença e qualidade de vida dos doentes diabéticos: estudo observacional em farmácias comunitárias. Rev Port Sau Pub. 2016;34(1):11-9.

22. Ferreira MC, Tozatti ], Fachin SM, Oliveira PP, Santos RF, Silva MER. Redução da mobilidade funcional e da capacidade cognitiva no diabetes melito tipo 2. Arq Bras Endocrinol Metab. 2014;58(9):946-52.

23. Alvarenga PP, Pereira DS, Anjos DMC. Mobilidade funcional e função executiva em idosos diabéticos e não diabéticos. Rev Bras Fisioter. 2010;14(6):491-6.

24. Freitas EF, Moreira OC, Oliveira CEP, Doimo LA, Loch MR. Prevalência de diabetes mellitus e prática de exercício em indivíduos que procuraram atendimento na estratégia saúde da família de Viçosa/MG. Rev Educ Fis. 2015;26(4):549-56.

25. Eid LP, Leopoldino SAD, Ollerm GASAO, Pompero DA, Martins MA, Gueroni LPB. Factors related to self-care activities of patients with type 2 diabetes mellitus. Esc Anna Nery. 2018;22(4): e20180046. 